\title{
Assessing stakeholders' perceptions and values towards social-ecological systems using participatory methods
}

\author{
Grace B Villamor ${ }^{1,2^{*}}$, Ignacio Palomo ${ }^{3,4}$, Cesar A López Santiago ${ }^{4}$, Elisa Oteros-Rozas ${ }^{4}$ and Joe Hill ${ }^{5}$
}

\begin{abstract}
Introduction: Many conservation initiatives for managing social-ecological landscapes factor in the best available biophysical information. However, insufficient consideration of social aspects can render such initiatives ineffective. By incorporating stakeholders' perceptions and values, and by involving stakeholders (transparently) in decision-making processes, conservation plans and efforts can better achieve desired goals and targets.

Results: In this paper, we present and analyze three case studies within different ecological and land use contexts. Each case study uses different participatory approaches to elicit stakeholders' perceptions and values, while seeking to involve stakeholders in the decision-making process. The case studies are the following: (1) participatory scenario planning for a protected area in Doñana coastal wetland in Southwestern Spain; (2) assessment of ecosystem services trade-offs and social responses on rewards for agro-biodiversity in the rubber agroforest landscape in Jambi, Indonesia; and (3) socio-cultural evaluation, through visual stimuli, of ecosystem services provided by transhumance cultural landscapes in Central Spain. We discuss how stakeholders perceive and value their environments and to what extent participatory approaches are useful for capturing information relating to land use and ecological processes.

Conclusions: Social-ecological systems are inherently complex, having a variety of interacting actors with different types of ecological knowledge, interests, and values. Different participatory tools or approaches are appropriate for various and specific contexts and objectives. Determining and integrating the various types of knowledge and values of different actors can contribute to a more comprehensive understanding of social-ecological systems.
\end{abstract}

Keywords: Actors; Ecosystem services; Ecological knowledge; Social processes; Socio-cultural valuation; Values

\section{Introduction}

Social-ecological system (SES) frameworks are being promoted for understanding ecological processes at the landscape level, in recognition that insufficient consideration of social systems can render the management or conservation of such ineffective systems (Mascia et al. 2003; Ban et al. 2013). SES frameworks conceptualize human/social and natural/ecological systems as coupled systems in which people interact with natural components, drawing on theories about the co-evolutionary nature of human and biophysical systems (Norgaard 1994). The study of the complex interactions between the

\footnotetext{
*Correspondence: gracev@uni-bonn.de

'Department of Ecology and Natural Resources Management, Center for Development Research (ZEF), University of Bonn, 53113, Bonn, Germany ${ }^{2}$ World Agroforestry Centre (ICRAF), Jl. Situ Gede, 16115 Bogor, Indonesia Full list of author information is available at the end of the article
}

biophysical and social components of SES, conceptualized as a set of subsystems, can provide a deeper knowledge of the overall system. SES frameworks' major features include the analysis of complex interactions and feedbacks between human and natural systems, the integration of tools and techniques from both the ecological and social sciences, and require an interdisciplinary study team to address common research questions (Liu et al. 2007). Moreover, the frameworks entail the study of ecosystem services through socio-cultural assessments, crucial to identifying the perceptions of individuals, institutions, and organizations towards ecosystem services, based on their preferences, needs, values, norms, and aspirations (Cowling et al. 2008).

In confronting the challenges to the planning and management of SESs, we need to deal with a variety of actors or stakeholders such as scientists, policy makers, 
private sector actors, and community-based resource users. By incorporating the stakeholders' perceptions and values, and by seeking to involve stakeholders (transparently) in decision-making processes, conservation plans and efforts will likely better achieve desired goals and targets (Young et al. 2013). Scientific information that we feed into the planning and assessing exercises is likely to be effective in influencing the public only if that information is perceived by the relevant stakeholders as legitimate, credible, and salient (Cash et al. 2003). In most cases, disputes exist among different stakeholders due to differences in their interests, values, and goals (i.e., short-term vs. longterm goals or recreational over subsistence needs). Thus, careful consideration of differing viewpoints is necessary to avoid biased decisions or top-down policy-led or scienceled judgments regarding the management of SES.

To date, most ecosystem service studies have focused primarily on monetary and biophysical approaches to valuation/assessment, while few studies have explored the more intangible socio-cultural perceptions and preferences (Nieto-Romero et al. 2013; Vihervaara et al. 2010). Valuation methods are not ideologically neutral (Gómez-Baggethun et al. 2010), but rather culturally (and politically) constructed and, as such, act as valuearticulating institutions that influence the articulation of decision-making processes related to the environment (Vatn 2005). Nevertheless, considering values is a way to understand what matters to people and the motivations underlying their decisions. Moreover, a consideration of values allows for the differentiation of ecosystem services, benefits, and values that are often conflated in the literature (Chan et al., 2012). However, it is very difficult to encompass the multiple dimensions of values systems in a single methodological approach. Any value-eliciting approach may tackle a complex combination of various dimensions of values, which are always context dependent. Chan et al. (2012) present a comprehensive typology of value dimensions, connected to a set of ecosystem services and benefits, and advocate a multi-method approach to better match the diversity of values linked to the interplay of ecosystems and societies.

SES thinking has remained superficial in many studies. For example, some of the tools or approaches to investigate the interactions in SESs tend to promote opposing views of nature and society. The properties of ecosystems and societies are supposed to be considered equally, and recognition is given to normative factors (e.g., cultural values, power relations) for understanding social change (ibid.). Moreover, (physical) scientists have perceived the study of ecological processes using quantitative and top-down methods to be precise and the analysis of social processes by qualitative, bottom-up methods to be less precise. More recently, it has been recognized and accepted that the use of qualitative methods (including participatory approaches) is valid and necessary for the evaluation of ecological processes and values. A growing number of qualitative and semiquantitative methods are now in use; however, certain issues still need to be resolved. For example, the metrics of preference in surveys of individual choice, and the use of subjective scaling to understand participative and deliberative processes, need to be compared to acknowledge their complementarities as well as the appropriate conditions under which these methods are most efficient. For better environmental management, policy makers and decision makers need a variety of tools and methods that allow social and ecological analyses of social-ecological processes and systems.

In this paper, we present and analyze three case studies within different ecological contexts and land uses, each of which use participatory approaches to draw out stakeholders' preferences and perceptions and to involve stakeholders in the decision-making process. The case studies are the following: (1) participatory scenario planning for a protected area in Doñana coastal wetland in Southwestern Spain; (2) assessment of ecosystem services trade-offs in a rubber agroforest landscape in Jambi, Indonesia; and (3) assessment of ecosystem services using a visual-stimulus approach in the transhumance cultural landscapes of Central Spain. Our main objective is to compare and contrast several participatory approaches used in environmental assessments in order to assess their main advantages and limitations. The specific objectives of this study are as follows: (1) to describe the application, in different contexts, of several participatory methods, namely participatory scenario planning, participatory ecosystem service assessment of trade-offs, and participatory evaluation of ecosystem services through visual preferences; (2) to evaluate the extent to which ecological aspects as articulated by stakeholders were assessed by each method; and (3) to assess the different value conceptions captured by each methodology and how this might influence overall results.

\section{Methods}

To achieve the above-mentioned objectives, we have prepared a conceptual framework (Figure 1) that captures the degree of participation that any method allows, models in a simplistic three-fold manner the stakeholders involved, according to the types of knowledge they possess, and provides a schematic detailing of the various dimensions of values that stakeholders can possess. In this section, we elaborate upon these three components, while in the subsequent section we describe in depth each of the three case studies, the participatory methods implemented and the key actors involved, with summaries of the results. Then follows a discussion and the conclusion. 


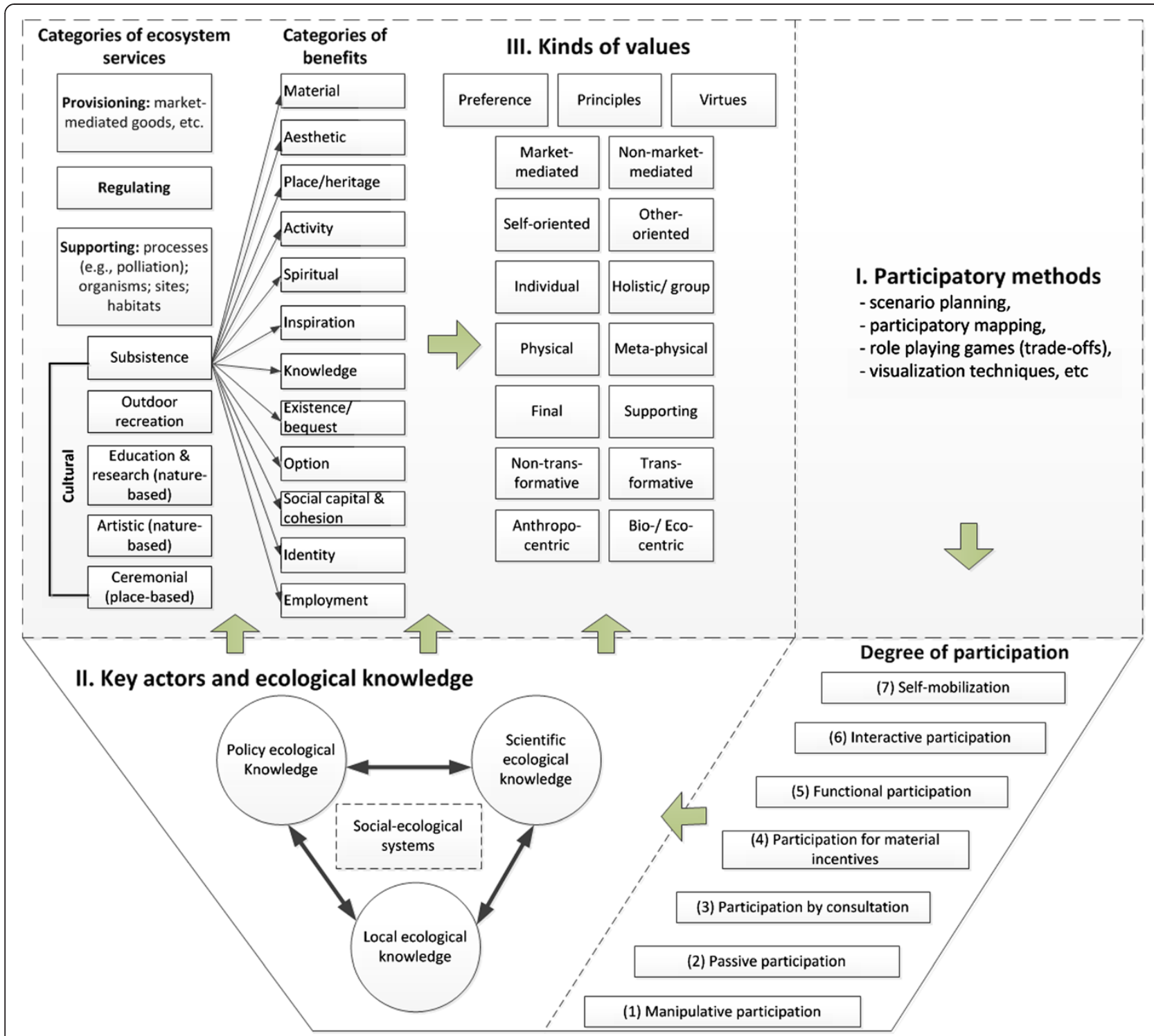

Figure 1 Conceptual framework. Conceptual framework integrating (I) degrees of participation the methods provide Pretty et al. (1995:61), (II) types of ecological knowledge of different actors, and (III) eight dimensions of values related to different categories of ecosystem services and benefits (Chan et al. 2012, p.13).

To analyze the degree of participation a method allows, we follow the typology described by Pretty et al. (1995:61), elaborated as follows:

(1) Manipulative participation - participation is a pretense, stakeholders have unelected representatives;

(2) Passive participation - stakeholders are told what has been decided or happened while information being shared belongs only to professionals (e.g., scientists/ researchers, extension services personnel);

(3) Participation by consultation - stakeholders are consulted or asked to answer questions. External actors define the problems and information gathering processes, and control the analysis;
(4) Participation for material incentives - actors contribute resources (e.g., labor) in return for food, cash, or other materials, but are not involved in either the experimentation or the process of learning;

(5) Functional participation - actors are involved in forming groups to meet predetermined objectives related to a project or experiment;

(6) Interactive participation - actors participate in joint analysis, seek multiple perspectives, and make use of systematic and structured learning processes; and

(7) Self-mobilization - actors take initiatives independently of external institutions to change systems, develop contacts with other external actors for technical 
advice and resources, while retaining control over how resources are used.

To conceptually separate the stakeholders and their knowledge systems, we use a three-fold distinction of ecological knowledge, distinguishing between local, policy, and scientific. This three-fold schematic was developed by the lead author in her Indonesian research, and perhaps fits less well to the two Spanish case studies due to the different social and political economic conditions between these countries. The three knowledge types are the following:

- Local ecological knowledge - the rich cumulative body of knowledge, practice, and belief evolving by adaptive processes and handed down through generations by cultural transmission, about the relationship of living beings with one another and with their environment (Berkes and Folke 1998; Berkes et al. 2000). Although many studies have explored the role of local ecological knowledge in perceiving and understanding diverse environmental features and changes, fewer studies have actually linked these cognitions with measured changes in behaviors (Berkes et al. 2000).

- Policy ecological knowledge - ecological knowledge shaped by the rules, regulations, and maps that exist for politically defined territorial and natural resources jurisdictions. The actors having such knowledge include government agencies, policy makers, local authorities, and non-government organizations (NGOs), mostly engaged in projects with short-term impacts. However, they may have access to data that is otherwise unavailable to local people (Voinov and Gaddis 2008). This data can often be provided to scientists or researchers if permission is granted.

- Scientific ecological knowledge - a type of knowledge generated from the representation of complex systems and processes and analyzed through scientific approaches, e.g., deductively and/or inductively to seek generic mechanisms (van Noordwijk 2011).

We adopt Chan et al.'s (2012) eight dimensions of values to analyze the values elicited during the decisionmaking processes. Of the existing literature on ecosystem services values, we consider Chan et al. (2012) to be the most comprehensive particularly on conforming to cultural services (as well as non-use values). Figure 1 shows that since many ecosystem services co-produce cultural benefits, full characterization of services (especially nonmaterial values) is only possible using diverse methods drawn from the social sciences.
The eight dimensions of values include the following:

(1) Preferences vs. principles vs. virtues - follows a division of ethical theories;

(2) Market-mediated vs. non-market-mediated - this differs from the market/non-market valuation dichotomy of economics;

(3) Self-oriented vs. others-oriented - distinguishes concern for oneself vs. others, thus for example, allowing perspectives of those who cannot represent themselves to be taken into consideration;

(4) Individual vs. holistic/group - most valuation methods orient towards one or the other;

(5) Experiential/physical vs. metaphysical - objects valued for their contribution to valued existence and for their existence independent of experience;

(6) Supporting vs. final (instrumental vs. inherent) - things valued because they help to produce things, other values inherent in that they are the desired ends;

(7) Transformative vs. non-transformative - thing or process valued for its contribution to a transformation in values, or valuable in reference to unchanging values;

(8) Anthropocentric vs. biocentric/ecocentric - values held by humans or non-humans.

\section{Results}

(1) Participatory scenario planning for a protected area in Doñana Social-Ecological System in Southwestern Spain

The Doñana social-ecological system (Doñana SES) consists of four ecodistricts (marsh, aeolian sheets, estuary, and coast) (Montes et al., 1998). The Doñana marsh, covering $1,660 \mathrm{~km}^{2}$, is one of Europe's biggest coastal wetlands and maintains a high biodiversity that delivers multiple ecosystem services, including biodiversity conservation, nature tourism, and water regulation (ZorrillaMiras et al. 2014). The social system includes several institutions, some of which have shaped the past and present of Doñana, such as the Doñana Protected Area. Nonetheless, in the previous decades, much of the marshes were transformed into agricultural lands. As a result, the protected area is surrounded by a matrix dedicated to agriculture which mainly delivers food (Palomo et al. 2014). The most important crops being produced are rice and red fruits, many of which are exported to other countries, while non-irrigated farming has declined in the last decades.

Although the earlier abrupt land use changes have now stabilized, many uncertainties still exist such as the effects of climate change, recent mine spills from a private company operating nearby, and excessive and unexplained mortalities of fauna in the recent past. Moreover, there are several conflicting interests in the region, and there is a need to create shared visions of the future for the region. These were the reasons that led to a participatory scenario 
planning process for assessing uncertainty in the future evolution of Doñana and to propose pathways towards a desirable future until 2035 (Palomo et al. 2011). The project was funded by the World Wildlife Fund (WWF), one of the most active NGOs in the region.

\section{i. Participatory research methods}

The methodology employed in the participatory scenario planning is described in Palomo et al. (2011). Participants worked in groups in which professional facilitators helped guide the process. Each group comprised actors from all three knowledge categories (Figure 1), in order to foster discussion between different interest groups and to reach consensus. The two workshops lasted one and a half days in total and included three phases: from the past to the present, scenario building, and back-casting. The past to the present phase included a participatory assessment of the evolution of Doñana SES during the last decades. This was followed by the scenario building exercise, in which stakeholders created four scenarios for the Doñana SES towards the year 2035. Finally, the back-casting methodology was applied in order to obtain from participants management recommendations that would facilitate approaching a desirable future, taking into account the four scenarios created. In the future scenarios, besides social or economic aspects, the actors were asked to describe different ecological characteristics such as the state of the wetland, biodiversity, or land uses across the landscape.

\section{ii. Actors and preferences}

A total of 52 actors participated in the two workshops in 2009. The diverse background, values, and preferences of the participants influenced the workshops' outcomes. In general, the preferences of stakeholders ranged between those who favor economic development driven by agriculture and tourism and those supporting a better conservation of the area. Many showed intermediate preferences, located between these extreme visions. The actors can be grouped in the following categories, although it can be noted that in many cases these categories overlap:

- Actors with local ecological knowledge: farmers (7), livestock raisers (4), hunters (2), and honeybee keepers (1). The preference of this group was mainly towards regulations that allowed the continuance of their livelihood practices and hence, less legal restrictions. Some stakeholders, such as the organic farmers, were concerned with environmental problems and supported more strict ecological production standards. Other actors invited to the workshops, such as professional shellfish gatherers, did not attend.

- Actors with policy ecological knowledge: managers from the protected area (7), administrators from the municipalities (7), regional water agency (2), regional environmental office (3), local sustainability agency (3), NGO representatives (3), environmental education professionals (3), representatives of the private sector related to tourism (2), and journalists (2). In this group, there was a wide range of preferences, among which many actors had a preference for an 'intermediate' outcome between conservation and development.

- Actors with scientific knowledge: researchers from different universities and research centers (6). Those researchers who focused on biological aspects had preferences that tended to more environmentally sustainable outcomes. The social scientists' preferences were also oriented to sustainable results but in a more socially inclusive manner. In this sense, one aspiration of the researchers was to reach a consensus among participants for what they perceived to be a sustainable future.

\section{iii. Ecological aspects assessed}

Different ecological aspects, mainly related to biodiversity, water, agriculture, and tourism, were discussed and analyzed during the workshops. Moreover, since the state of ecosystem services was assessed in each scenario, underlying ecological aspects were discussed by the participants regarding their interconnections with social aspects and human well-being. For example, when issues dealing with water quality and biodiversity inside the protected area were discussed, these were related to other aspects such as use of water in agriculture, water management in the watershed, or the transportation sector in the area which is responsible for high mortality of fauna.

\section{iv. Main values elicited}

The kinds of values elicited within a deliberative process are very diverse. Given the nature of the method used, in which ecosystem services trends were assessed and linked to human well-being, there was a broad space for the inclusion of multiple values (though note that monetary valuation of ecosystem services was not performed). As most of the outcomes of the workshops were obtained deliberatively, group values as well as others-oriented values (as opposed to individual values) were emphasized. The medium- to long-term perspective that the scenario method brings into the discussion most probably facilitates the inclusion of supporting and final values as the focus is in a story instead of in a snapshot (which would be favoring only the final values).

(2) Participatory assessment of ecosystem services trade-offs for a rubber agroforest landscape in Jambi, Indonesia: mapping and role-playing game

In Jambi province, Sumatra, Indonesia, rubber agroforests are being replaced by export-oriented monoculture 
plantations such as rubber and oil palm. The rubber agroforest, or jungle rubber system, is a complex multistrata canopy that is similar to natural secondary forests (Gouyon et al. 1993; Michon 2005). It also supports lowland tropical forest diversity, as it serves as a corridor for diverse flora and fauna and represents a substantial carbon stock. Since most of the lowland tropical forests in Sumatra have been converted to plantations of rubber and oil palm, assessing the possible ecosystem services trade-offs during the conversion of rubber agroforests is crucial to support decision-making. The study area is located in the foothills of Kerinci-Seblat Natural Park in Bungo district, Jambi Province. Three villages (Desa Buat, Lamang Panjang and Lubuk Beringin), containing the last remaining rubber agroforests in the province, were investigated.

\section{i. Participatory research methods}

Participatory mapping and land use role-playing games at the watershed level (total area of $160 \mathrm{~km}^{2}$ ), were used to determine the local perceptions of rubber agroforest farmers. The results of these approaches, combined with a household survey $(N=196)$, were incorporated in an agent-based model (Villamor 2012) to assess the potential trade-offs of introducing payment for ecosystem services (PES) schemes.

The aim of the participatory mapping was to integrate local stakeholders' perceptions of the different land use types and institutional properties (i.e., ownership, customary, protected, and production areas). Google Earth maps were used, which give good visual images of the actual land cover in the area, with key landmarks (e.g., roads, bridges, schools, and houses) clearly visible. A total of 95 household respondents, including the village heads and a representative of Warung Konservasi (WARSI, a local NGO) jointly identified household farm plots. Placing tracing paper over the map, respondents were able to sketch the roads to their farm plots, their neighboring farms, and other relevant spatial information (i.e., distance of market or pick-up stations). Later, the data were processed using GIS and exported to Netlogo (i.e., an agent-based model platform) (Villamor et al. 2014).

The aim of the role-playing game was two-fold: 1) to identify the preferred land-use types that meet villagers' objectives under varying scenarios, and 2) to determine the social response of villagers to external actors promoting conservation of rubber agroforests through payments for ecosystem services schemes or conversion of rubber agroforest into oil palm and rubber plantations (Villamor and van Noordwijk 2011; Villamor et al. 2013). In the game, three land-use game boards, which represented each village landscape, were used. The players were the same respondents who joined in the participatory mapping exercise. Using the game boards as simulators, the players could directly decide and change the village landscape in response to their negotiations with external agents. Roles such as oil palm and logging concessionaires, government, local NGO (promoting biodiversity conservation) representatives were played by the villagers, matching as much as possible the real life roles of external agents. To make the game more realistic and to test how land-use preferences change while meeting people's targets, we integrated some scenarios such as socio-economic shocks and natural calamities. During the game, only village leaders were involved; no private sector actors were invited to participate.

\section{ii. Actors and preferences}

The following actors were involved:

- Actors with local ecological knowledge are the men and women in the villages. The majority of the men are rubber tappers while women are responsible for the production of the staple food, rice. Though the area is endowed with rich natural resources, these villages are considered poor, having little access to markets, roads, communication, and electricity infrastructure. Reciprocity and trust are high in the area (Akiefnawati et al. 2010). Research has revealed that men prefer to conserve both forests and rubber agroforests as a source of income and timber. Women prefer to maintain rubber agroforests, which supports the supply of the water needed to generate electricity from mini-hydroelectric power, to irrigate rice fields and to supply drinking water (Villamor et al. 2013). However, due to low yields and low financial returns from rubber agroforests as compared to monoculture rubber and oil palm, the villagers are attracted to convert their agroforests to monoculture.

- The actor having policy ecological knowledge is the provincial government of Jambi that aims for economic development of its territorial domain. Officially, it considers the monoculture rubber and oil palm plantations as engines for economic growth in the province. Nevertheless, environmental conservation, via support of protected areas as the easiest and cheapest option, is also its stated objective.

- Actors with scientific ecological knowledge are the conservation agencies such as the WARSI, the World Agroforestry Centre, and the lead author of this paper (referred to as researcher in the remaining part of this section), who aim to reconcile the land use preferences of the local people and the provincial government. These actors prefer forests and agroforests due to the rich biodiversity such land uses support, and perceive the establishment of a PES scheme as a win-win option especially for rubber agroforests. 


\section{iii. Ecological aspects assessed}

Soil restoration (e.g., fallow practices), flood regulation as maintained by trees, biodiversity functions (e.g., pest control and predation), and regeneration of high-valued timber trees are the ecological functions and processes most often expressed by actors during the role-playing games and participatory mapping activities. Women are mostly interested in maintaining a certain distance between their village vegetable gardens and rubber agroforests because wild boars may destroy their vegetables. On the other hand, the majority of men prefer to maintain blocks of forest and agroforest within their landscapes because of their use of timber for house construction. Both males and females tend to locate environmentally destructive land use such as coal mining away from their village settlements. It was also observed that actors at the local level have a strong explicit understanding of ecological processes as well as spatial relations (e.g., upstream and downstream water flows).

Researcher and respondents agreed that microclimate, water regulations and water quality are among examples of indirect benefits from rubber agroforests. These correspond with the findings of scientific studies that show how rubber agroforests' functions resemble those of secondary forests' (Long and Nair 1999; Beukema et al. 2007; Gouyon et al. 1993; Tomich et al. 2001). Furthermore, the role-playing games highlighted the differences in land-use preferences between females and males - that females preferred more profitable land uses (e.g., oil palm) while males preferred forest and rubber agroforests (Villamor et al. 2013).

\section{iv. Main values elicited}

Although the majority of the values elicited fall into the material aspects (i.e., goods such as timber, food, and water) as anthropocentric value (Figure 1), a transformative kind of value (i.e., if it is valuable in reference to unchanging values and perspectives, Chan et al. (2012)) was drawn out from the mapping and role-playing games. For example, the wild boar might be seen as a pest from the women's perspective, while overall there is no preexisting preference for or against preservation of wild boar, since the species is not part of the local peoples' dietary intake -due to religious reasons- and thus may be perceived as valueless. On the other hand, the wild boar is part of the food web of the larger animals (e.g., Sumatran tigers); therefore, its presence maintains a balance in the biological system and so the value of the wild boar is biocentric (Figure 1). Another interesting value elicited from the game is that of non-market-mediated. The study villages have a matrilineal inheritance system for their rice paddies, and (one of the ways) men claim land rights (is) by planting rubber trees (van Noordwijk et al. 2012), thus as compared to women, men showed a preference for more rubber agroforest.
(3) Assessment of ecosystem services using a visual-stimulus approach in the transhumance cultural landscapes of the Central Spain (Cuenca and Ciudad Real provinces)

Transhumance is a customary pastoralist practice consisting of the seasonal migration of livestock between ecological regions following peaks in pasture productivity (Ruiz and Ruiz 1986). A network of legally protected drove roads connects summer and winter pastures, which are the most outstanding feature of transhumance landscapes. This livestock movement has declined in Spain since the eighteenth century (Ruiz and Ruiz 1986; García-Martín 2004; Oteros-Rozas et al. 2013), but some herds still continue to migrate on foot. This is the case of the Conquense Drove Road (CDR), one of the longest and most frequently walked drove roads today. CDR consists of a 75-m wide and approximately 410-km long corridor that crosses a mosaic of agroecosystems comprising cereals, sunflowers, vineyards, olive groves, some remnants of Mediterranean oak forest in Castilla-La Mancha (Cuenca and Ciudad Real provinces), and pine forests in the Serranía de Cuenca and Sierra de Albarracín (Cuenca and Terual provinces). The study area was characterized as a social-ecological network (Oteros-Rozas et al. 2012b).

Transhumance has been acknowledged as an important traditional farming practice for provisioning services such as wool and high-quality meat, regulating services such as seed dispersal, and cultural services such as cultural identity and traditional ecological knowledge, while also contributing to biodiversity conservation (Gómez Sal and Lorente 2004; Bunce et al. 2006; Manzano and Malo 2006; Oteros-Rozas et al. 2012a). Experts consider the livestock route as a key corridor linked to landscape connectivity playing an important role on cultural landscape sustainability and biodiversity conservation.

Using a visual-stimulus approach (photographs), we explored the preferences and perceptions of stakeholders about the ecosystem services provided by two different landscapes and the perceived effect of the Conquense Drove Road (López-Santiago et al. 2014). The project within which this research was embedded had the main objective of identifying and assessing ecosystem services provided by transhumance and related ecosystems, to provide insights for decision-making that allow the maintenance of drove roads and transhumance. The precise aim of this research was to elicit actors' preferences and perceptions of ecosystem services through use of visual stimuli.

\section{i. Participatory research methods}

The visual method used has been recognized as an effective research tool for the study of human-ecosystem relationships (e.g., Daniel 2001). Based on landscape perception surveys, the visual-stimuli approach was employed to explore the preferences and perceptions of ecosystem services provided by the two main landscapes (croplands and 
forests) crossed and connected by the CDR (López-Santiago et al. 2014). Following Pretty et al's (1995) typology, participation is in this case 'by consultation' and designed to inform decision makers about the preferences, perceptions, and values of citizens and scientists strongly linked to the research problem.

Data were obtained in the form of standardized questionnaires $(N=314)$ applied in face-to-face interviews. Participants were shown two pairs of very similar photographs (one pair for a cropland and the other for a pine forest), with each picture in a pair differing by the presence or not of the drove road. The participants were asked to state their preference for one photograph of each pair and also to score their perceived delivery of a list of 16 ecosystem services (previously identified through a literature review and in-depth semi-structured interviews in another phase of the research (Oteros-Rozas et al., 2012b)), using a semi-quantitative scale from 1 (nothing) to 4 (very high). Quantitative analysis used descriptive statistics (mean frequencies and standard deviations), and Wilcoxon's rank-sum tests were performed to identify and describe differences in ecosystem service perceptions between landscapes and the presence of the CDR. To explore how underlying socio-cultural variables might have influenced the perception of ecosystem services, we applied a multivariate model of redundancy analysis (Rao 1964) that showed the relationship between perception values and the socio-cultural attributes of respondents.

\section{ii. Actors and preferences}

The participants of the survey were local inhabitants, regular visitors, and scientists:

- Actors with local ecological knowledge and values: herders and the people residing in the small villages in the transhumance summering area (Cuenca) showed a marked preference for landscapes with drove roads and appreciated pastures, livestock, fire prevention, connectivity, esthetic value, cultural identity, and tourism. Contrastingly, farmers living in La Mancha (Ciudad Real) (a cropland landscape crossed by the drove road) mostly appreciated their cultural identity and hunting. They did not exhibit a preference for the drove road landscape and saw more esthetic value when it is absent. Showing yet further diversity within this grouping, local people living in nearby small cities, as well as regular visitors from larger cities, preferred views of the landscape without a drove road. They related such views with the provision of tranquility/relaxation, woodland, air purification, and plant regeneration.

- Actors with policy knowledge and values: village heads and staff of regional development agencies, NGOs, and government administration were approached and interviewed during other phases of the larger research project. For this particular exercise, we did not survey them because the focus was to explore perceptions among actors linked to the study area (e.g., local inhabitants and visitors) and among environmental students.

- Actors with scientific knowledge and values: environmental sciences researchers and students were attracted by the presence of a drove road but were of the view that ecological connectivity, cultural identity, and esthetics are greater when a drove road is absent.

\section{iii. Ecological aspects assessed}

The visual pair-wise comparison methodology creates a preference index through a choice act based on paired comparison (with or without the presence in the pictures of key landscape elements). At the same time, it gives participants the opportunity to assign a value to many ecological aspects, as they were directly interrogated about their perceptions of the delivery of ecosystem services. Many of these aspects were directly linked to ecological functioning (regulating services), such as air purification, plant regeneration, soil erosion, habitat for species, connectivity, or fire prevention; and some others were indirectly linked as provisioning ecosystem services for humans: gathering, feed for animals, food from agriculture, wood and timber, and livestock.

\section{iv. Main values elicited}

The main values elicited from this case study for each stakeholder group (according to Chan et al. 2012, Figure 1) were the following:

- Herders and locals of small villages at the study area exhibit values associated to pastoralism and linked to their traditional cultural identity -'non-transformative' - still as part of their livelihood linked to livestock, currently mediated also by tourism, outdoor recreation, educational, or other cultural demands. It is the most complex and multiple set of values found.

- La Mancha's farmers have a strong cultural identity, values, and feelings linked to their local cropland-like landscape. Hunting is an important part of this. The farmers also have a complex mixture of values similar to those of the herders but with important contextdependent preferences for Mediterranean crops (vineyards and olive groves) and lesser affinity for (if not some aversion to) transhumance and livestock. Given the local economy, we could say that these are largely 'physical' values.

- Environmental-friendly people show highly 'bio-centric' values and it seems as if a conflict arises between this way of thinking and their knowledge of transhumance's positive ecological impact. 
- Urban people's preferences were indicators of recreational-consumerist demands, mostly 'self-oriented' and 'metaphysical'.

\section{Discussion}

Several authors have highlighted the need for participatory approaches to be used to improve environmental decisionmaking (Reed 2008; Ban et al. 2013). Comparison of the three case studies presented here allows us to identify some of the pros and cons of each of the participatory methods used. However, this comparative assessment is limited because the three methods were applied in different socioecological contexts, and therefore, differences across them are caused by both the methods and the contexts. Nonetheless, we consider that the three methods presented are different enough to allow a cross comparison, considering them as complementary.

The Doñana case study might be considered a functional participatory approach (see Reid et al., 2009). The main advantage of such participatory scenario planning (PSP) is that it allows an integrative analysis of complex systems, addresses uncertainty, and can be combined with a back-casting technique to develop concrete management proposals. In PSP, ecological and social considerations are assumed to be interlinked and affecting multiple aspects in the scenarios. This process is therefore useful for complex systems that face high uncertainty. An advantage of the approach is that all kinds of stakeholders might participate in the process because no formal knowledge is needed. However, given that many issues are analyzed, it is also possible that few of them are analyzed in very much detail. In addition, the PSP process is very demanding in terms of time and team effort. Thus PSP can be applied as a general approach that uncovers the main values, aspirations, fears and trade-offs between social groups, and can be complemented with other more specific methods to allow for a more in-depth focus on specific concrete issues.

Supporting/final values elicited by PSP can be considered as a powerful asset to understand complex issues and foster long term thinking. Group values might facilitate the achievement of decisions by consensus, making the method appropriate for SES in which stakeholders have $a$ priori divergent interests (Vervoort et al. 2014). In relation to the three knowledge types, some of the participants that we grouped within the 'local ecological knowledge' were older than those in the other two knowledge groups and, as a result, felt less comfortable in the participatory workshops. Therefore, although this methodology is inclusive of different knowledge types, it is still important to choose adequate methodologies within PSP and to facilitate the inclusion of all knowledge types into the discourse during the participatory process.

The role-playing games were used in Indonesia's Jambi province to understand whether the land-use preferences of households and village heads aligned with those other actors. Since the concept of ecosystem services is vague for local people (and no local translation is available), the term was translated in a way that local people could understand. For this reason, the concept was explored by contrasting the direct and indirect benefits (lansung or tidak langsung in Bahasa Indonesia) of each land use (Figure 1). Nevertheless, because role-playing games are highly interactive for the players, it is likely that all the actors involved gained valuable insights into one another's' values and preferences. Many studies have attested to this (Dionnet et al. 2008; Pahl-Wostl 2006). The participatory mapping approach, on the other hand, allowed the information collected from a survey to be cross-checked with other stakeholders who

Table 1 A comparison of the three participatory methods employed in understanding ecological processes

\begin{tabular}{|c|c|c|c|c|}
\hline $\begin{array}{l}\text { Participatory method/ } \\
\text { case study }\end{array}$ & Types of participation $^{a}$ & $\begin{array}{l}\text { Typologies of stakeholders } \\
\text { that can be included }\end{array}$ & $\begin{array}{l}\text { Level and type of analysis } \\
\text { of ecological aspects }\end{array}$ & $\begin{array}{l}\text { Main kind of } \\
\text { values elicited }\end{array}$ \\
\hline $\begin{array}{l}\text { Participatory scenario } \\
\text { planning in Doñana } \\
\text { coastal wetland, Spain }\end{array}$ & $\begin{array}{l}\text { Participation in information } \\
\text { giving/Functional } \\
\text { participation }^{\text {b }}\end{array}$ & All & $\begin{array}{l}\text { Broad analysis of ecological } \\
\text { aspects focusing more upon } \\
\text { the interrelations among factors }\end{array}$ & $\begin{array}{l}\text { Others-oriented values, } \\
\text { group values, } \\
\text { supporting values }\end{array}$ \\
\hline $\begin{array}{l}\text { Participatory mapping } \\
\text { in rubber agroforest } \\
\text { landscape, Indonesia }\end{array}$ & $\begin{array}{l}\text { Participation by consultation/ } \\
\text { Functional participation }\end{array}$ & All & $\begin{array}{l}\text { Administrative boundaries and } \\
\text { land use types, location of water } \\
\text { sources, production and critical } \\
\text { conservation areas }\end{array}$ & $\begin{array}{l}\text { Anthropocentric and } \\
\text { bio-centric values, group } \\
\text { and physical values }\end{array}$ \\
\hline $\begin{array}{l}\text { Role playing games } \\
\text { in rubber agroforest } \\
\text { landscape, Indonesia }\end{array}$ & Interactive participation & $\begin{array}{l}\text { Depending on the research } \\
\text { objective/s }\end{array}$ & $\begin{array}{l}\text { Abstract representation of } \\
\text { ecological processes and dynamics }\end{array}$ & $\begin{array}{l}\text { Anthropocentric and } \\
\text { bio-centric values, } \\
\text { transformative and } \\
\text { non-transformative } \\
\text { values, non-market- } \\
\text { mediated values }\end{array}$ \\
\hline $\begin{array}{l}\text { Evaluation of visual } \\
\text { preferences in } \\
\text { transhumance cultural } \\
\text { landscapes, Spain }\end{array}$ & Participation by consultation & $\begin{array}{l}\text { Depending on the research } \\
\text { objective/s }\end{array}$ & $\begin{array}{l}\text { Perception of ecosystem services } \\
\text { delivery, some directly and some } \\
\text { indirectly but all, linked to } \\
\text { ecological aspects }\end{array}$ & $\begin{array}{l}\text { Physical and } \\
\text { metaphysical, } \\
\text { bio-centric, } \\
\text { self-oriented values }\end{array}$ \\
\hline
\end{tabular}

${ }^{\mathrm{a}}$ Based on Pretty et al. (1995).

${ }^{\mathrm{b}}$ This method has the potential to allow the introduction of interactive participation. 
were familiar with the context or location. For instance, during the household survey, depending on which household member was available to provide information, information may be under or overestimated. The checking allowed a level of legitimacy to be assumed. Nonetheless, during the participatory activity, males and females had different perceptions of space or spatial extent of the landscape as well as land marks in the landscapes important for delivering ecosystem services. Incorporating this information into the ecosystem service trade-offs assessment could minimize biases in recommending decisions (or solutions).

In the third case study, the exploration of the visual perception of ecosystem services through photographs (López-Santiago et al. 2014) helped to reveal different stakeholder groups according to their values and types of knowledge. Visual surveys are quick and easy for interviewees. They provide a measure of social perception of ecosystem service delivery in a constructed metric consisting of a numeric scale associated to rating categories. Both ecosystem services with a market value and those with no market value are equally identified, thus a wide range of material and non-material links between society/individuals and nature are incorporated. Following the model of value dimensions offered by Chan et al. (2012), the visual method is apt to elicit market-mediated values such as those linked to provisioning services plus some cultural services such as tourism and hunting. Further, this method could also be used to elicit non-market-mediated values such as those arising from appreciating regulating services and the rest of cultural services. The concept of ecosystem services allows prioritization of self-oriented, individual, experiential and anthropocentric values, but makes less easy the elicitation of some others-oriented, holistic, existence/bequest and biocentric values.

A quantitative approach allows the objective grouping of stakeholders not only according to their socioeconomic characteristics but also regarding their links to SES, their visions of the subject under investigation, and their type of knowledge. These complement other qualitative and more participatory/deliberative tools.

Since conservation interventions require changes in human behavior to succeed (Mascia et al. 2003), sociocultural approaches should be considered flagship for ecosystem services assessments (Cowling et al. 2008; Chan et al. 2012; Martin-Lopez et al. 2007; Oteros-Rozas et al. 2014). Consequently, we argue that the involvement of stakeholders, as well as social scientists in research about ecosystem services, is a challenge that could be critical to target regional conservation and sustainability goals together with the well-being of human populations. A comparison of the three approaches related to depth of analysis of ecological processes, type of stakeholders that can be included, main kind of values elicited, etc. is shown in Table 1. From this study, new research questions for the future arise that we could not tackle due to time requirement and cases for comparison, such as Can the design of a research project to use methods that allow for higher degrees of participation facilitate the elicitation of a wider variety of actors' values and perceptions? How does the degree of participation relate to the variety of perceptions and values that are revealed by participants?

\section{Conclusions}

We have presented three case studies that use different participatory approaches (with a strong emphasis on socio-cultural aspects) to explore how stakeholders' knowledge, preferences, perceptions, and values are integrated in social-ecological assessments. Social-ecological systems are inherently complex and include a variety of actors with different interests and values that interact. It is therefore crucial to select which participatory tools or approaches are appropriate for each specific context and objective. Moreover, recognizing and integrating the various types of knowledge and values of different actors contributes to a more comprehensive understanding of the dynamics and processes of social-ecological systems. This, we argue, is needed in the context of a search for collectively designed and supported solutions to socially rooted ecological problems.

\section{Abbreviations}

CDR: Conquense Drove Road; LEK: local ecological knowledge; NGO: non-government organization; PEK: policy ecological knowledge; PES: payments for ecosystem services; PSP: participatory scenario planning; SEK: scientific ecological knowledge; SES: Social-ecological systems; WARSI: Warung Konservasi; WWF: world wildlife fund.

\section{Competing interests}

The authors declare that they have no competing interests.

\section{Authors' contributions}

GBV, IP, and JH conceptualized and designed the paper. GBV, IP, EOR, and CLS carried out the case studies presented, performed the analysis, and wrote the manuscript. GBV, IP, EOR, CLS, and JH reviewed and commented on various versions of the manuscript. All authors read and approved the final manuscript.

\section{Acknowledgements}

The authors wish to thank all the people who collaborated on the projects presented here, especially those who participated in the research/workshops. We are grateful to the anonymous reviewers for their valuable comments.

\section{Author details}

${ }^{1}$ Department of Ecology and Natural Resources Management, Center for Development Research (ZEF), University of Bonn, 53113, Bonn, Germany. ${ }^{2}$ World Agroforestry Centre (ICRAF), Jl. Situ Gede, 16115 Bogor, Indonesia. ${ }^{3}$ Basque Centre for Climate Change (BC3), Alameda Urquijo 4, 48008 Bilbao, Spain. ${ }^{4}$ Department of Ecology, Social-Ecological Systems Laboratory, Universidad Autónoma de Madrid, Madrid 28049, Spain. ${ }^{5}$ Department of Political and Cultural Change, Center for Development Research (ZEF), University of Bonn, 53113 Bonn, Germany.

Received: 26 June 2014 Accepted: 27 September 2014

Published online: 05 November 2014 


\section{References}

Akiefnawati R, Villamor GB, Zulfikar F, Budisetiawan I, Mulyoutami E, Ayat A, van Noordwijk M (2010) Stewardship agreement to reduce emissions from deforestation and degradation (REDD): Lubuk Beringin's hutan desa as the first village forest in Indonesia. Int For Rev 12(4):349-360

Ban NC, Mills M, Tam J, Hicks CC, Klain S, Stoeckl N, Bottrill MC, Levine J, Pressey RL, Satterfield T (2013) A social-ecological approach to conservation planning: embedding social considerations. Front Ecol Environ 11(4):194-202

Berkes F, Folke C (1998) Linking social and ecological systems: management practices and social mechanisms for building resilience. Cambridge University Press, Cambridge

Berkes F, Colding J, Folke C (2000) Rediscovery of traditional ecological knowledge as adaptive management. Ecol Appl 10(5):1251-1262

Beukema H, Danielsen F, Vincent G, Hardiwinoto S, van Andel J (2007) Plant and bird diversity in rubber agroforests in the lowlands of Sumatra, Indonesia. Agrofor Syst 70:217-242

Bunce R, De Aranzabal I, Schmitz M, Pineda F (2006) A review of the role of Drove Roads (Cañadas) as ecological corridors. Wageningen, Alterra

Cash DW, Clark WC, Alcock F, Dickson NM, Eckley N, Guston DH, Jäger J, Mitchell RB (2003) Knowledge systems for sustainable development. Proc Natl Acad Sci 100(14):8086-8091. http://www.pnas.org/content/100/14/8086.full

Chan K, Satterfield T, Goldstein J (2012) Rethinking ecosystem services to better address and navigate cultural values. Ecol Econ 74:8-18

Cowling RM, Egoh B, Knight AT, O'Farrell PJ, Reyers B, Rouget M, Roux DJ, Welz A, Wilhelm-Rechman A (2008) An operational model for mainstreaming ecosystem services for implementation. Proc Natl Acad Sci 105(28):9483-9488

Daniel TC (2001) Whither scenic beauty? Visual landscape quality assessment in the 21st century. Landsc Urban Plan 54(1):267-281

Dionnet M, Kuper M, Hammani A, Garin P (2008) Combining rope-playing games and policy simulation exercises: an experience with Moroccan smallholder farmers. Simulation \& Gaming 39:498

García-Martín P (2004) The history and characteristics of the Mesteña Transhumance Routes. Transhumance and Biodiversity in European Mountains' Report from the EU-FP5 project Transhumount IALE Publication Series (1):255-258

Gómez Sal A, Lorente I (2004) The present status and ecological consequences of transhumance in Spain. Transhumance and biodiversity in European mountains, In, pp 233-248

Gómez-Baggethun E, de Groot R, Lomas PL, Montes C (2010) The history of ecosystem services in economic theory and practice: from early notions to markets and payment schemes. Ecol Econ 69(6):1209-1218

Gouyon A, de Foresta H, Levang P (1993) Does 'Jungle Rubber' deserve its name? An analysis of rubber agroforesty system in Southeast Asia. Agrofor Syst 22:181-200

Liu J, Dietz T, Carpenter SR, Folke C, Alberti M, Redman CL, Schneider SH, Ostrom E, Pell AN, Lubchenco J, Taylor WW, Ouyang Z, Deadman P, Kratz T, Provencher W (2007) Coupled human and natural systems. AMBIO: A Journal of the Human Environment 36(8):639-649, doi:10.1579/0044-7447(2007)36 [639:chans] 2.0.co;2

Long AJ, Nair PKR (1999) Trees outside forests: agro-, community, and urban forestry. New For 17:145-174

López-Santiago CA, Oteros-Rozas E, Martín-López B, Plieninger T, Martín EG, González JA (2014) Using visual stimuli to explore the social perceptions of ecosystem services in cultural landscapes: the case of transhumance in Mediterranean Spain. Ecol Soc 19(2):27. http://dx.doi.org/10.5751/ES-06401-190227

Manzano P, Malo JE (2006) Extreme long-distance seed dispersal via sheep. Front Ecol Environ 4(5):244-248

Martin-Lopez B, Montes C, Benayas J (2007) The non-economic motives behind the willingness to pay for biodiversity conservation. Biol Conserv 139:67-82

Mascia MB, Brosius JP, Dobson TA, Forbes BC, Horowitz L, McKean MA, Turner NJ (2003) Conservation and the social sciences. Conserv Biol 17(3):649-650

Michon G (2005) Domesticating forests: how farmers manage forest resources. IRD, CIFOR and ICRAF, Bogor, Indonesia

Montes C, Borja F, Bravo MA, Moreira JM (1998) Reconocimiento Biofísico de Espacios Naturales Protegidos. Doñana: Una Aproximación Ecosistómica. Consejería de Medio Ambiente, Junta de Andalucía, Sevilla, España

Nieto-Romero M, Oteros-Rozas E, González JA, Martín-López B (2013) Exploring the knowledge landscape of ecosystem services assessments in Mediterranean agroecosystems: insights for future research. Environmental Science \& Policy.

Norgaard R (1994) Development betrayed: the end of progress and a coevolutionary revisioning of the future, 1994. Routledge, London
Oteros-Rozas E, González J, Martín-López B, López C, Montes C (2012a) Ecosystem services and social-ecological resilience in transhumance cultural landscapes: learning from the past, looking for a future. In: Plieninger T, Bieling C (eds) Resilience and the cultural landscape understanding and managing change in human-shaped environments. Cambridge University Press, Cambridge, pp 242-260

Oteros-Rozas E, González JA, Martín-López B, López CA, Zorrilla-Miras P, Montes C (2012b) Evaluating ecosystem services in transhumance cultural landscapes: an interdisciplinary and participatory framework. GAIA: Ecological Perspectives for Science \& Society 21(3):185-193

Oteros-Rozas E, Martín-López B, López CA, Palomo I, González JA (2013) Envisioning the future of transhumant pastoralism through participatory scenario planning: a case study in Spain. The Rangeland Journal 35(3):251-272

Oteros-Rozas E, Martín-López B, González JA, Plieninger T, López CA, Montes C (2014) Socio-cultural valuation of ecosystem services in a transhumance social-ecological network. Reg Environ Chang 14(4):1269-1289

Pahl-Wostl C (2006) The importance of social learning in restoring the multifunctionality of rivers and floodplains. Ecol Soc 11(1):10

Palomo I, Martín-López B, López-Santiago C, Montes C (2011) Participatory scenario planning for protected areas management under the ecosystem services framework: the doñana social-ecological system in southwestern Spain. Ecology \& Society 16(1):23

Palomo I, Martín-López B, Zorrilla-Miras P, Del Amo DG, Montes C (2014) Deliberative mapping of ecosystem services within and around Doñana National Park (SW Spain) in relation to land use change. Reg Environ Chang 14(1):237-251

Pretty JN, Guijt I, Thompson J, Scoones I (1995) Participatory Learning and Action: A Trainer's Guide. IIED Participatory Methodology Series, International Institute for Environment and Development. London

Rao C (1964) The use and interpretation of principal component analysis in applied research. Sankhyā. The Indian Journal of Statistics Series A :329-358

Reed MS (2008) Stakeholder participation for environmental management: a literature review. Biol Conserv 141(10):2417-2431

Reid H, Alam M, Berger R, Cannon T, Huq S, Milligan A (2009) Community-based adaptation to climate change: an overview. Participatory learning and action 60(1):11-33

Ruiz M, Ruiz J (1986) Ecological history of transhumance in Spain. Biol Conserv 37(1):73-86

Tomich TP, van Noordwijk M, Budidarsono S, Gillison A, Kusumanto T, Murdiyarso D, Stolle F, Fagi AM (2001) Agricultural intensification, deforestation, and the environment: assessing tradeoffs in Sumatra, Indonesia. Tradeoffs or synergies :221-244

van Noordwijk M (2011) Linking sustainability and agroforestry science to multifunctional policy action, Sixth GCHERA Conference Proceedings.

van Noordwijk M, Leimona B, Jindal R, Villamor GB, Vardhan M, Namirembe $S$, Catacutan D, Kerr J, Minang PA, Tomich TP (2012) Payments for environmental services: evolution toward efficient and fair incentives for multifunctional landscapes. Annu Rev Environ Resour 37(1):389-420, doi:10.1146/annurev-environ-042511-150526

Vatn A (2005) Institutions and the environment. Edward Elgar, Cheltenham Vervoort JM, Thornton PK, Kristjanson P, Förch W, Ericksen PJ, Kok K, Ingram JSI, Herrero M, Palazzo A, Helfgott AES, Wilkinson A, Havlík P, Mason-D'Croz D, Jost C (2014) Challenges to scenario-guided adaptive action on food security under climate change. Global Environ Change 28:383-394. doi:http://dx.doi. org/10.1016/j.gloenvcha.2014.03.001

Vihervaara P, Rönkä M, Walls M (2010) Trends in ecosystem service research: early steps and current drivers. Ambio 39(4):314-324

Villamor GB (2012) Flexibility of multi-agent system models for rubber agroforest landscapes and social response to emerging reward mechanisms for ecosystem services in Sumatra. Indonesia University of Bonn Press, Bonn

Villamor GB, van Noordwijk M (2011) Social role-play games vs individual perceptions of conservation and PES agreements for maintaining rubber agroforests in Jambi (Sumatra), Indonesia. Ecol Soc 16(3):27

Villamor GB, Desrianti F, Akiefnawati R, Amaruzaman S, van Noordwijk M (2013) Gender influences decisions to change land use practices in the tropical forest margins of Jambi. Mitigation and Adaptation Strategies for Global Change, Indonesia, pp 1-23, doi:10.1007/s11027-013-9478-7

Villamor GB, Le QB, Djanibekov U, van Noordwijk M, Vlek PLG (2014) Biodiversity in rubber agroforests, carbon emissions and rural livelihoods: multi-agent, 
multi-dimensional simulation tool to preview policy scenarios in lowland Sumatra. Environ Model Softw 61:151-165

Voinov A, Gaddis EIB (2008) Lessons for successful participatory watershed modeling: a perspective from modeling practitioners. Ecol Model 216(2):197-207

Young JC, Jordan A, R Searle K, Butler A, S Chapman D, Simmons P, Watt AD

(2013) Does stakeholder involvement really benefit biodiversity conservation? Biol Conserv 158:359-370

Zorrilla-Miras P, Palomo I, Gómez-Baggethum E, Martín-López B, Lomas PL (2014)

Effects of land-use change on wetland ecosystem services: a case study in the

Doñana natural areas marshes, SW Spain. Landsc Urban Plan 122:160-174

doi:10.1186/s13717-014-0022-9

Cite this article as: Villamor et al.: Assessing stakeholders' perceptions

and values towards social-ecological systems using

participatory methods. Ecological Processes 2014 3:22.

\section{Submit your manuscript to a SpringerOpen ${ }^{\circ}$} journal and benefit from:

- Convenient online submission

- Rigorous peer review

- Immediate publication on acceptance

- Open access: articles freely available online

- High visibility within the field

- Retaining the copyright to your article

Submit your next manuscript at $\gg$ springeropen.com 